\title{
Diving behavior of the giant devil ray in the Mediterranean Sea
}

\author{
Simonepietro Canese*, Andrea Cardinali, Teresa Romeo, Michela Giusti, \\ Eva Salvati, Michela Angiolillo, Silvestro Greco
}

\author{
Italian National Institute for Environmental Protection and Research (ISPRA), \\ Department for Habitat and Biodiversity Protection, Via di Casalotti 300, 00166, Rome, Italy
}

\begin{abstract}
The giant devil ray Mobula mobular is the only mobulid species regularly present in the Mediterranean Sea. The spatial ecology and biology of this species are poorly known, and given its high bycatch mortality, low reproductive capacity, and limited range, it is listed as Endangered (A4d) on the IUCN Red List. Most of the information concerning this species has been obtained through bycatch data and opportunistic sightings. To inform conservation and management actions, it is necessary to conduct research on the behavior of giant devil rays. This study is the first attempt to systematically describe the diving behavior of this species. Three specimens were tagged with popup satellite tags in the Messina Strait (central Mediterranean Sea) during summer 2007. Two tags were programmed to detach after $120 \mathrm{~d}$ and 1 after $60 \mathrm{~d}$. The data revealed that these fish dove to depths between 600 and $700 \mathrm{~m}$. However, they spent most of their time $(81.5 \%)$ between the surface and $50 \mathrm{~m}$, in waters with temperatures between 20 and $29^{\circ} \mathrm{C}$. The preference for shallow depth and warm surface waters exposes this species to threats such as accidental captures in driftnets and surface longlines.
\end{abstract}

KEY WORDS: Giant devil ray $\cdot$ Mobula mobular $\cdot$ Diving behavior $\cdot$ Satellite tag $\cdot$ Mediterranean Sea

\section{INTRODUCTION}

The giant devil ray Mobula mobular is the only mobulid species present in the Mediterranean Sea (Notarbartolo di Sciara \& Bianchi 1998). It is the largest of the genus Mobula, reaching a maximum disk width (DW) of $5.20 \mathrm{~m}$ (McEachran \& Seret 1990). This species occurs in the Mediterranean Sea (with the exception of the Northern Adriatic Sea) in offshore deep waters and, occasionally, in shallow waters (Bradai \& Capapé 2001). Outside the Mediterranean, it occurs along the coast of Africa (from Morocco to Senegal), near the Canary Islands, Madeira, the Azores, Portugal, and, as a vagrant, off the coast of southern Ireland (Notarbartolo di Sciara \& Bianchi 1998). However, because expert examination is needed to distinguish $M$. mobular from the spinetail devil ray $M$. japonica (Notarbartolo di Sciara 1987), past reports of giant devil rays from the
Atlantic may be attributed to incorrect identification of spinetail devil rays (Notarbartolo di Sciara et al. 2006). As suggested by Notarbartolo di Sciara et al. (2006), this species appears to live in very low densities throughout its range. However, at present, there are no population estimates.

Like all mobulids, the giant devil ray is an epipelagic batoid (Brito 1991). It feeds on planktonic crustaceans and small schooling fishes which get trapped on its specialized branchial filter plates (McEachran \& Capapé 1984). In the Mediterranean, a likely important prey item for the giant devil ray is the euphausiid shrimp Meganyctiphanes norvegica (Orsi Relini \& Cappello 1992) along with small mesopelagic and clupeid fishes (Celona 2004).

Although in the Mediterranean there is no direct fishery for giant devil rays, high mortality rates were reported for this species from accidental takes in 
swordfish pelagic driftnets (MuñozChapuli et al. 1993). Giant devil rays have also occasionally been reported as bycatch from longlines (Orsi Relini et al. 1999), purse seines, trawls (Bauchot 1987), pelagic trawls (Scacco et al. 2009), trammel nets (Bradai \& Capapé 2001), and traditional fixed tuna traps (Boero \& Carli 1979).

The giant devil ray is included in Annex II ('List of endangered or threatened species') of the Protocol concerning Special Protected Areas and Biological Diversity in the Mediterranean of the Barcelona Convention, enforced in 2001. Given presumed high bycatch mortalities, its limited reproductive capacity (Wourms 1977), and range, Mobula mobular has been listed as Endangered (A4d) by IUCN (Notarbartolo di Sciara et al. 2006).

Information concerning the ecology and the behavior of this species is very scarce and has largely been obtained

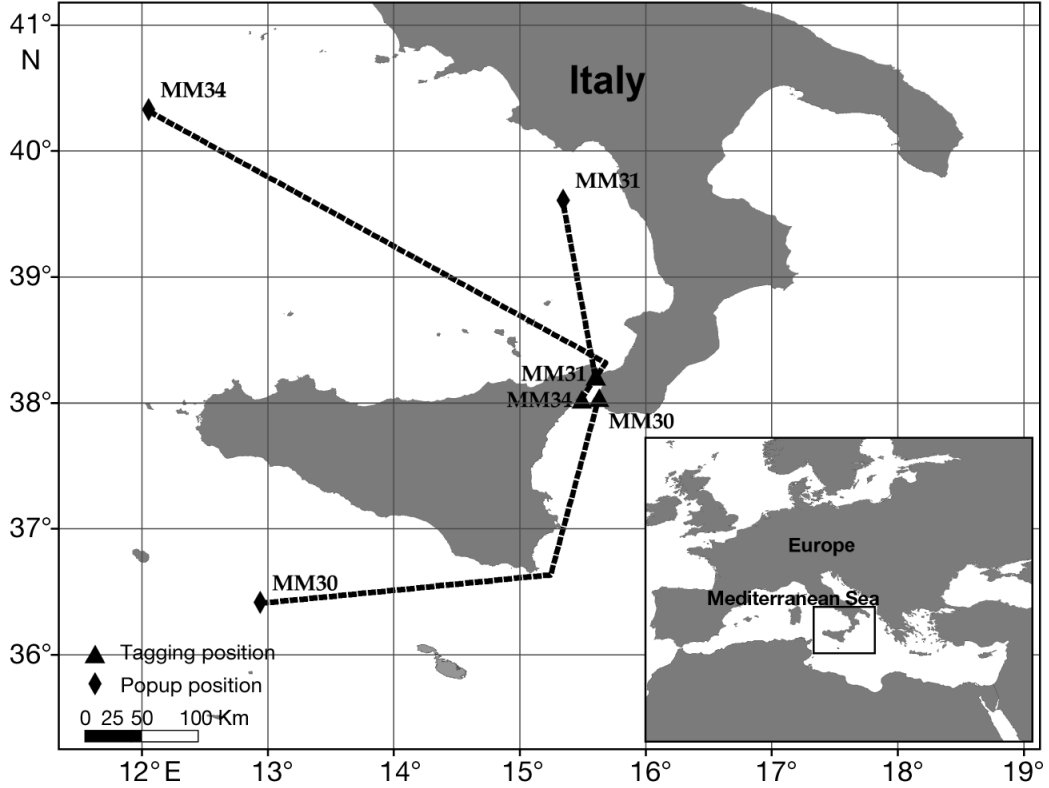

Fig. 1. Mobula mobular. Tagging ( $\mathbf{\Delta})$ and detachment $(\bullet)$ locations of giant devil rays tagged in the Messina Strait (central Mediterranean Sea) during summer 2007 from opportunistic observations. No systematic effort has been made to study this species in its natural environment. Considering the high impact of human activities throughout the whole Mediterranean basin, it is important to understand their spatial ecology to identify and protect critical habitat. Our study represents the first attempt to describe the diving behavior of giant devil rays in the Mediterranean Sea. Although the tagging of only 3 animals cannot lead to any conclusive information on the behavior of this species, it provides useful data on which to base further studies.

\section{MATERIALS AND METHODS}

During summer 2007, 3 giant devil rays, visually estimated by experienced fishers to have a DW between 2.5 and $3 \mathrm{~m}$, were tagged with Mk10-PAT (pop-up archival transmitting) tags (Wildlife Computers). Tagging took place in the Messina Strait (Fig. 1), central Mediterranean Sea, where the presence of giant devil ray aggregations during spring and summer is well documented (Celona 2004). The operations were conducted onboard a 'felucca', a traditional local fishing boat, characterized by a $25 \mathrm{~m}$ long gangway and a $25 \mathrm{~m}$ high mast, specifically built and equipped to catch swordfish with harpoons (Fig. 2). Giant devil rays were sighted from the mast while they were swimming slowly very close to the surface (<1 m deep), sometimes in a group. They were approached and tags were applied using a $4 \mathrm{~m}$ long aluminum pole (Fig. 2). Tagging data are summarized in Table 1.

Tags were secured to the animals with tethers and medical grade nylon anchors (Prince \& Goodyear 2006) inserted $16 \mathrm{~cm}$ deep into the dorsal musculature of the wing. Tags were programmed to detach from the animals after $120 \mathrm{~d}$ ( 2 ind.) and $60 \mathrm{~d}$ (1 ind.).

MK10-PAT tags were programmed to automatically summarize and transmit depth and water temperature data in four $6 \mathrm{~h}$ intervals (starting at 00:00 GMT; local

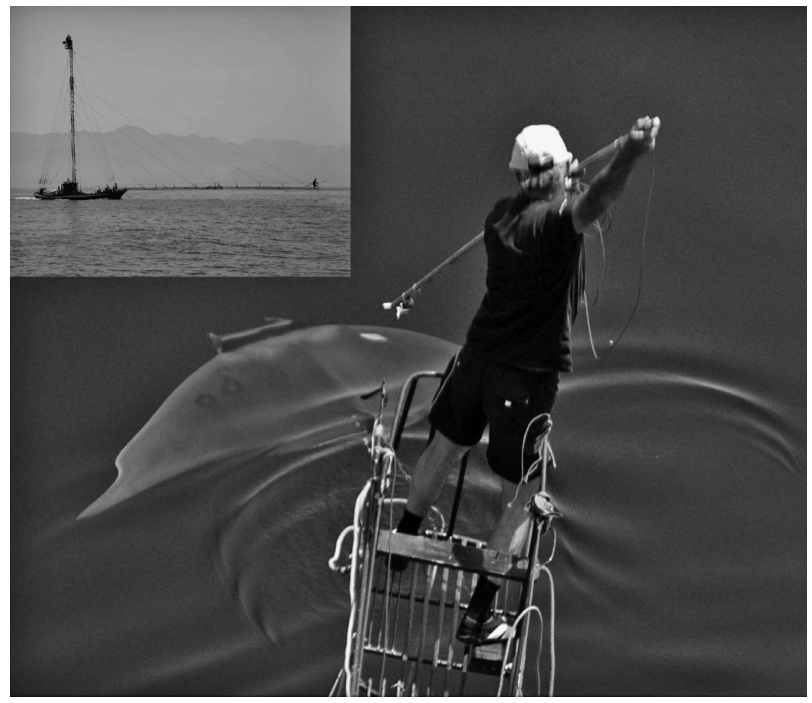

Fig. 2. Tagging operation at the far end of the gangway of the felucca boat (inset) 
Table 1. Mobula mobular. Summary of tagging events showing the estimated disk width (DW) of giant devil rays tagged in the Messina Strait (central Mediterranean Sea) during summer 2007, and information on tagging and detachment of tags

\begin{tabular}{|c|c|c|c|c|c|c|c|c|}
\hline \multirow[b]{2}{*}{ Tag ID } & \multirow[b]{2}{*}{$\mathrm{DW}(\mathrm{m})$} & \multicolumn{3}{|c|}{ — Tagging } & \multicolumn{3}{|c|}{ - Detachment } & \multirow{2}{*}{$\begin{array}{l}\text { Distance } \\
\quad(\mathrm{km})\end{array}$} \\
\hline & & Date & Latitude $\left({ }^{\circ} \mathrm{N}\right)$ & Longitude $\left({ }^{\circ} \mathrm{W}\right)$ & Date & Latitude $\left({ }^{\circ} \mathrm{N}\right)$ & Longitude $\left({ }^{\circ} \mathrm{W}\right)$ & \\
\hline MM30 & 2.5 & 20 June 2007 & 38.0383 & 15.6290 & 18 October 2007 & 36.4150 & 12.9400 & 298 \\
\hline MM34 & 3 & 25 June 2007 & 38.0267 & 15.4908 & 23 October 2007 & 40.3260 & 12.0550 & 337 \\
\hline MM31 & 3 & 3 August 2007 & 38.2090 & 15.6037 & 2 October 2007 & 39.6080 & 15.3450 & 278 \\
\hline
\end{tabular}

time $=\mathrm{GMT}+2$ ). For each of these temporal intervals, tags were set to record the time spent in 14 unequal depth categories, from surface to $1000 \mathrm{~m}(0,10,20,50$, $100,150,200,300,400,500,600,700,800,1000 \mathrm{~m})$, and in 14 water temperature intervals of $1^{\circ} \mathrm{C}$ increments (from 13 to $25^{\circ} \mathrm{C}$ and $>25^{\circ} \mathrm{C}$ ). After detaching, tags surfaced and started transmitting the collected data, as time at depth and time at temperature histograms, via the Argos system, which also calculates the geographic position of transmitting tags. The four $6 \mathrm{~h}$ intervals were selected considering the limited performance of Argos in the Mediterranean Sea (Gaspar \& Malardé 2007) and represent a tradeoff between the need for a low number of intervals, necessary to maximize the chances of retrieving full day data sets, and the need for a high number of intervals, necessary for maintaining higher accuracy when describing giant devil ray diving behavior throughout the day. In addition to the time and depth histograms, tags generated and transmitted daily profiles of depth and temperature (PDTs), recording maximum and minimum temperatures at 8 depth intervals.

Because animals were tagged in the same period, they were all adults. Given the small sample size, data from the 3 tags were pooled.

To evaluate whether diving behavior is influenced by sunlight, depth data were grouped in two $12 \mathrm{~h}$ periods, from 06:00 to $18: 00 \mathrm{~h}$ and from 18:00 to $06: 00 \mathrm{~h}$; these intervals, even if they are not strictly correlated to the time of sunset or sunrise, comprise most of the day and night, at least during summer.

Differences in the average time spent at different depth and temperature intervals between day and night were tested with a Student's $t$-test, and differences in the $6 \mathrm{~h}$ intervals were tested with an analysis of variance (ANOVA). Means $\pm \mathrm{SD}$ are given in the text.

\section{RESULTS}

During the tagging procedure, the 3 giant devil rays did not show any avoidance behavior towards the approaching boat, but they reacted to tagging with a fast burst and a vertical dive.
All tags detached at the pre-established time, 298, 337 , and $278 \mathrm{~km}$ from where the animals were tagged. The first animal moved south while the other 2 moved north (Fig. 1, Table 1). The average number of data packages transmitted by tags and successfully received by the Argos system was $196 \pm 39$ (SD).

The time at temperature and time at depth histograms transmitted by tags indicated that giant devil rays spent most of their time at depths between 0 and $50 \mathrm{~m}$ (average $=81.5 \pm 20 \%$; Fig. 3 ) and in water with temperatures between 20 and $29^{\circ} \mathrm{C}$ (maximum temperature registered in the PDTs; average $=78.5 \pm 21 \%$; Fig. 4). PDTs transmitted by the tags confirmed the presence of a clear thermocline close to a depth of $50 \mathrm{~m}$ in the study area (Fig. 5).

Occasionally, giant devil rays dove below the thermocline, reaching a maximum depth between 600 and $700 \mathrm{~m}$ (Fig. 3). The rays spent the majority of their time near the water surface (i.e. in the first $10 \mathrm{~m}$ depth) during both day $(49 \pm 25 \%$ of their time) and night ( $47 \pm$ $25 \%)$. No statistically significant differences were noted in use of surface waters between day and night

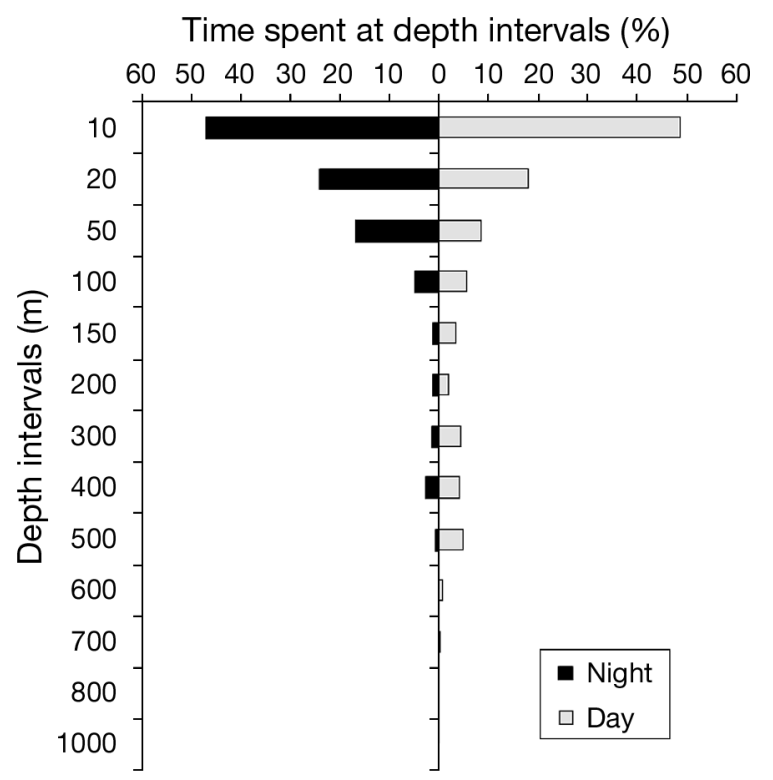

Fig. 3. Mobula mobular. Average proportions of time spent by giant devil rays at different depth intervals 
Time spent at temperature intervals (\%)

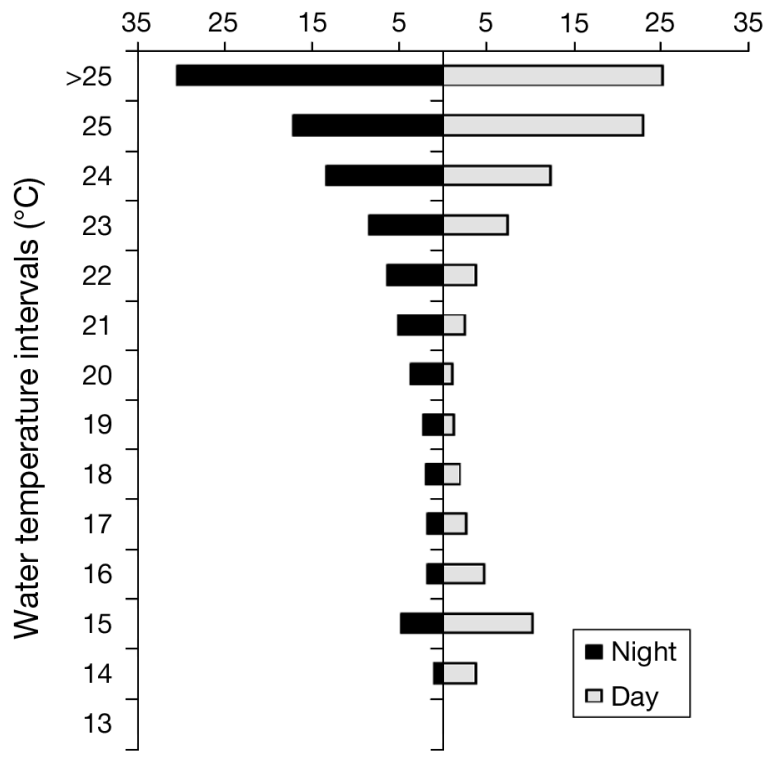

Fig. 4. Mobula mobular. Average proportions of time spent by giant devil rays at different temperature intervals

(Table 2). However, significant differences were found in their vertical distribution between day and night in the depth range of 0 to $50 \mathrm{~m}$ (above the thermocline). At night, $88 \pm 12 \%$ of their time was spent above the thermocline, and during the day, $75 \pm 24 \%$ of their time was spent in the same depth range (Student's $t_{1} F_{1,57}=$ $3.19, \mathrm{p}<0.001)$. The analysis conducted for thermal data confirmed the preference of giant devil rays for warmer water with temperature between 20 and $29^{\circ} \mathrm{C}$
Table 2. Mobula mobular. Average \pm SD proportions $(\%)$ of time tagged giant devil rays spent above $50 \mathrm{~m}$ during day and night

\begin{tabular}{|lcccc}
\hline \multirow{2}{*}{$\begin{array}{l}\text { Phase of } \\
\text { day }\end{array}$} & \multicolumn{4}{c}{ Depth intervals (m) } \\
\cline { 2 - 5 } & $0-10$ & $10-20$ & $20-50$ & $0-50$ \\
\hline Night & $47 \pm 25$ & $24 \pm 14$ & $17 \pm 15$ & $88 \pm 12$ \\
Day & $49 \pm 25$ & $18 \pm 18$ & $8 \pm 9$ & $75 \pm 24$ \\
\hline
\end{tabular}

at night, with an average proportion of $86 \pm 12 \%$; during the day, this proportion was $75 \pm 25 \%$ (Student's $t_{\text {, }}$ $\left.F_{1,31}=3.19, \mathrm{p}<0.05\right)$.

Giant devil rays spent significantly more time in the first $50 \mathrm{~m}$ of the water column from 18:00 to 00:00 $\mathrm{h}$ (ANOVA, $F_{3,54}=6.84, \mathrm{p}<0.001$ ), while in the morning from 6:00 to $12: 00 \mathrm{~h}$, they spent significantly more time at greater depth (Table 3 ).

\section{DISCUSSION}

The felucca represents an optimal platform for sighting and tagging giant devil rays. Specimens swimming at the surface or basking can easily be spotted from the top of its mast (Fig. 2) and can be readily approached for tagging through its extremely long gangway. The nylon anchor darts yielded good retention on this species with no premature releases. As such, we judged the overall tagging procedure applied in this study to be relatively efficient compared with other studies on different species (De Metrio et al. 2001, Sedberry \& Loefer 2001).
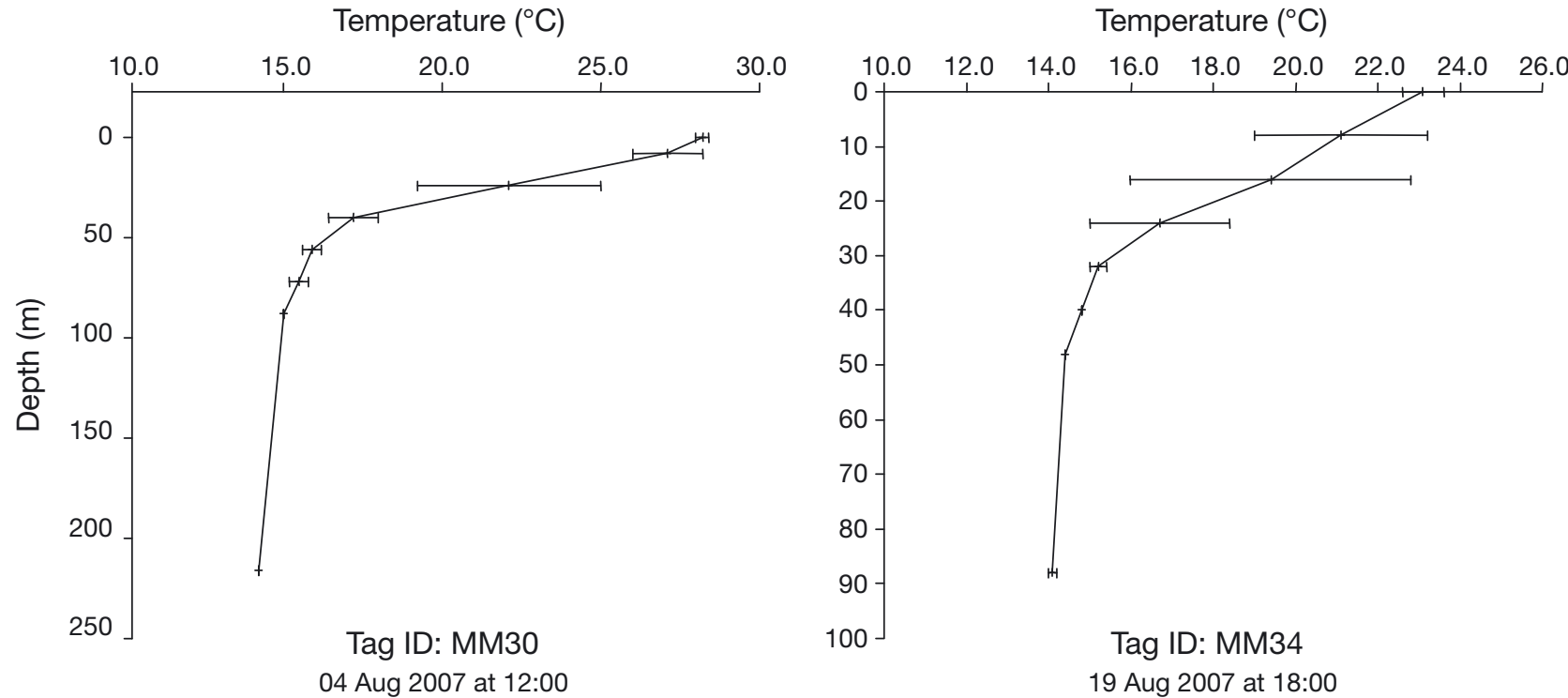

Fig. 5. Profiles of depth and temperature (PDTs) transmitted by satellite tags deployed on giant devil rays, showing the presence of a marked thermocline (horizontal bars indicate the range of recorded temperatures) 
Table 3. Mobula mobular. Average \pm SD proportions (\%) of time tagged giant devil rays spent above and below $50 \mathrm{~m}$ during 4 time intervals ( ${ }^{*}$ significant difference at $\mathrm{p}<0.05$ )

\begin{tabular}{|lcccc|}
\hline \multirow{2}{*}{$\begin{array}{l}\text { Depth } \\
\text { intervals (m) }\end{array}$} & $\begin{array}{c}\text { 00:00- } \\
\text { 06:00 }\end{array}$ & $\begin{array}{c}06: 00- \\
12: 00\end{array}$ & $\begin{array}{c}12: 00- \\
18: 00\end{array}$ & $\begin{array}{c}18: 00- \\
00: 00\end{array}$ \\
\hline $0-50$ & $77 \pm 11$ & $70 \pm 25$ & $85 \pm 17$ & $96 \pm 4^{*}$ \\
$50-700$ & $23 \pm 11$ & $30 \pm 25$ & $15 \pm 17$ & $4 \pm 4^{*}$ \\
\hline
\end{tabular}

The number of messages successfully retrieved by Argos was low compared to other similar studies conducted in open oceans (Gaspar \& Malardé 2007), confirming the limited performance of Argos in the Mediterranean Sea (Gaspar \& Malardé 2007). This represents a limiting factor for conducting studies that consider the use of low-power satellite tags in this area.

The presence of giant devil ray aggregations in the Messina Strait is a well documented seasonal event occurring annually between late spring and summer (Celona 2004). Celona (2004) hypothesized that the local availability of high densities of prey may be a factor in the attraction of giant devil rays to the area. Indeed, we noted that 1 animal caught in this area had a full stomach. As confirmed by our observation of the tagged animals, giant devil rays move away from the Messina Strait in the middle of fall; however, the swimming direction was not limited to north as anecdotally reported by local fishers (Celona 2004). The Messina Strait could represent an aggregation area where animals from different parts of the Mediterranean Sea congregate during late spring for feeding and/or breeding purposes. Strong site fidelity has been recently described for the giant manta ray Manta birostris in the Komodo Marine Park, Indonesia, and in several other locations (Dewar et al. 2008).

Giant devil rays, like other mobulids, are considered epipelagic (Brito 1991) as confirmed by this study. However, in our study area, this species also showed dives in very deep mesopelagic waters, down to $600 \mathrm{~m}$, even if only for a limited time. Deep dives have also been described for the Mediterranean fin whale Balaenoptera physalus that can dive deeper than $500 \mathrm{~m}$ (Panigada et al. 1999) when feeding on northern krill Meganyctiphanes norvegica. This euphuasiid also represents one of the known main prey items for giant devil rays in the Mediterranean Sea (Orsi Relini \& Cappello 1992, Celona 2004). We assume that the peculiar oceanographic conditions of the Mediterranean Sea, with deep-water temperatures of about $13^{\circ} \mathrm{C}$ (Hopkins 1985) and the mesopelagic habit of $M$. norvegica (Sardou et al. 1996) can induce this species to dive at these depths.

Giant devil rays do not follow the typical diving pattern of large planktivorous sharks like the basking shark Cetorhinus maximus (Sims et al. 2005) or the megamouth shark Megachasma pelagios (Nelson et al. 1997), which both show a definite vertical migration timed to meet the upwards vertical migration of zooplankton. Giant devil rays spent most of the time in the upper layers and executed deep dives that were not correlated to the time of day.

In mobulids, the general mechanisms regulating body temperature have not been identified (Alexander 1996), even though a counter-current heat-exchanger has been identified at least in the Chilean devil ray Mobula tarapacana (Alexander 1995). Therefore, the preference for warmer superficial water noted in this study supports the existing hypothesis that the giant devil ray's basking behavior is an adaptation for increasing its body temperature (Alexander 1996).

However, the preference for superficial waters exposes giant devil rays to accidental captures in driftnets or surface longlines. Our observations corroborate the hypothesis that these gears are amongst the main threats for giant devil rays in the Mediterranean Sea (Notarbartolo di Sciara et al. 2006).

Further studies are needed to elucidate the biology of giant devil rays, including long-range movements within and outside the Mediterranean Sea, and potential changes in winter behavior as described in basking sharks (Sims et al. 2003).

\section{LITERATURE CITED}

Alexander RL (1995) Evidence of a counter-current heatexchanger has been identified in the ray Mobula tarapacana (Chondrichthyes: Elasmobranchii: Batoidea: Mylobatiformes). J Zool (Lond) 237:377-384

Alexander RL (1996) Evidence of brain-warming in the mobulid rays, Mobula tarapacana and Manta birostris (Chondrichthyes: Elasmobranchii: Batoidea: Myliobatiformes). Zool J Linn Soc 118:151-164

Bauchot ML (1987) Raies et autres batoidés. In: Fischer M, Schneider M, Bauchot ML (eds) Fiches FAO d'identification des espèces pour les besoins de la peche. Méditerranée et Mer Noire. Zone de Peche 37. Révision 1 II. FAO, Rome, p 847-885

Boero F, Carli A (1979) Catture di Elasmobranchi nella tonnarella di Camogli (Genova) dal 1950 al 1974. Boll Mus Ist Biol Univ Genova 47:27-34

Bradai MN, Capapé C (2001) Captures du diable de mer, Mobula mobular, dans le Golfe de Gabés (Tunisie meridionale, Méditerranée centrale). Cybium 25:389-391

Brito A (1991) Catalogo de los pesces de las Islas Canarias. Francisco Lemus, La Laguna

Celona A (2004) Caught and observed giant devil rays Mobula mobular (Bonnaterre, 1788) in the Strait of Messina. Ann Ser Hist Nat 14:11-18

De Metrio G, Arnold GP, De la Serna JM, Yannopoulos C, Megalofonou P, Buckley AA, Pappalepore M (2001) Further results of tagging Mediterranean bluefin tuna with pop-up satellite-detected tags. Collect Vol Sci Pap ICCAT 52:776-783 
Dewar H, Mous P, Domeier M (2008) Movements and site fidelity of the giant manta ray, Manta birostris, in the Komodo Marine Park, Indonesia. Mar Biol 155:121-133

Gaspar P, Malardé JP (2007) Analysis of Argos system performance in the Mediterranean area for transmitters with weak output power such as pop-up tags. 2nd Int Symp Tagging and Tracking Marine Fish with Electronic Devices, October 8-11, 2007, Large Pelagics Research Center, University of New Hampshire, Durham, NH, p 94 (Abstract)

Hopkins TS (1985) Physics of the sea. In: Margalef R (ed) Western Mediterranean. Pergamon Press, New York, NY, p 100-126

McEachran JD, Capapé C (1984) Mobulidae. In: Whitehead PJP, Bauchot ML, Hureau JC, Nielsen J, Tortonese E (eds) Fishes of the north-eastern Atlantic and the Mediterranean, Vol 1. UNESCO, Paris, p 210-211

McEachran JD, Seret B (1990) Mobulidae In: Quero JC, Hureau JC, Karrer C, Post A, Saldanha L (eds) Check-list of the fishes of the eastern tropical Atlantic (CLOFETA), Vol 1. JNICT, Lisbon, SEI, Paris, and UNESCO, Paris, p 73-76

Muñoz-Chapuli R, Notarbartolo di Sciara G, Séret B, Stehmann M (1993) The status of the elasmobranch fisheries in Europe. Report of the Northeast Atlantic Subgroup of the IUCN Shark Specialist Group, June 1993, IUCN, Gland, Switzerland and Cambridge, UK

Nelson DR, McKibben JN, Strong WR, Lowe CG, Sisneros JA, Schroeder DM, Lavenberg RJ (1997) An acoustic tracking of a megamouth shark, Megachasma pelagios: a crepuscular diel vertical migrator. Environ Biol Fishes 49: 389-399

Notarbartolo di Sciara G (1987) A revisionary study of the genus Mobula Rafinesque, 1810 (Chondrichthyes: Mobulidae) with the description of a new species. Zool J Linn Soc 91:1-91

Notarbartolo di Sciara G, Bianchi I (1998) Guida degli squali e delle razze del Mediterraneo. Franco Muzzio Editore, Padova

Editorial responsibility: Steven Cooke, Ottawa, Ontario, Canada
Notarbartolo di Sciara G, Serena F, Mancusi C (2006) Mobula mobular. In: IUCN (ed) 2006 IUCN Red List of Threatened Species. Available at www.iucnredlist.org/

Orsi Relini L, Cappello M (1992) The fin whale and other large pelagic filterers as samplers of Meganyctiphanes norvegica. Rapp Comm Int Mer Méditerr 33:263

Orsi Relini L, Cima C, Garibaldi F, Palandri G, Relini M, Torchia G (1999) La pesca professionale con i palamiti galleggianti nel 'Santuario dei Cetacei' del Mar Ligure: si tratta di attività ecocompatibili? Biol Mar Mediterr 6: 100-109

Panigada S, Zanardelli M, Canese S, Jahoda M (1999) How deep can baleen whales dive? Mar Ecol Prog Ser 187: 309-311

Prince ED, Goodyear CP (2006) Hypoxia-based habitat compression of tropical pelagic fishes. Fish Oceanogr 15: 451-464

Sardou J, Etienne M, Andersen V (1996) Seasonal abundance and vertical distributions of macroplankton and micronekton in the northwestern Mediterranean Sea. Oceanol Acta 19:645-656

Scacco U, Consalvo I, Mostarda E (2009) First documented catch of the giant devil ray Mobula mobular (Chondrichthyes: Mobulidae) in the Adriatic Sea. Mar Biodiv Rec 2:e93 DOI: 10.1017/S1755267209001110

Sedberry GR, Loefer JK (2001) Satellite telemetry tracking of swordfish, Xiphias gladius, off the eastern United States. Mar Biol 139:355-360

Sims DW, Southall EJ, Richardson AJ, Reid PC, Metcalfe JD (2003) Seasonal movements and behaviour of basking sharks from archival tagging: no evidence of winter hibernation. Mar Ecol Prog Ser 248:187-196

Sims DW, Southall EJ, Tarling GA, Metcalfe JD (2005) Habitat-specific normal and reverse diel vertical migration in the plankton-feeding basking shark. J Anim Ecol 74: 755-761

Wourms JP (1977) Reproduction and development in chondrichthyan fishes. Am Zool 17:379-410

Submitted: June 26, 2008; Accepted: April 5, 2011

Proofs received from author(s): July 24, 2011 